\title{
DEVELOPMENT OF TABLE TENNIS LEARNING MEDIA BASED ON ANDROID APPLICATIONS
}

\author{
Melya Nur Herliana ${ }^{1}$, Haikal Millah², Selly Purnama ${ }^{3}$ \\ Universitas Siliwangi ${ }^{1,2,3}$ \\ melya.nh22@unsil.ac.id, haikal@unsil.ac.id, sellypurnama@unsil.ac.id
}

\begin{abstract}
This study aims to develop a table tennis learning media based on an android application that is tested for its product feasibility and can be used in lectures both online and as a guide in offline lectures. The research carried out was only up to the development or development stage because the other purpose of this research was only to develop and produce a table tennis learning media product based on an android application called "B-PONG" (Basic Ping-Pong). Ping-Pong is another name for table tennis and is already popular among the public. The instrument used in this research is a questionnaire/questionnaire given to experts/experts to determine or assess eligibility according to the validator's expertise so that it is validated by 3 experts/experts including table tennis material experts, physical education learning media experts, technical and informatics experts. In addition, a questionnaire/questionnaire is also given for users (students) to get feedback from users. The results of product validation indicate that the table tennis learning media "B-Pong" is categorized as good and suitable for use in the learning process. The results of the response to the use of the table tennis learning media product "B-Pong" are also categorized as good. Based on the results of the three experts, and the product usability test, the table tennis learning media product "B-Pong" is said to be feasible and can be used in the table tennis learning process. The next research plan will test the effectiveness of the product so that it can be seen the effect of "B-Pong" media when used in the table tennis learning process.
\end{abstract}

Keywords: Android Application, Learning Media, Table Tennis

Accepted: $19^{\text {th }}$ of January 2022

Correspondence author: Melya Nur Herliana, Universitas Siliwangi, Indonesia. E-Mail: melya.nh22@unsil.ac.id

DOI http://dx.doi.org/10.31851/hon.v5i1.6782 do

\section{(c) (i) (2)}

Jurnal Halaman Olahraga Nusantara licensed under a Creative Commons Attribution-ShareAlike 4.0 International License

\section{INTRODUCTION}

Advances in technology today can not be denied so influential in various aspects of life. Starting from studying, working, recreation, to stay in touch with family or other environments influenced by technological advances. Moreover, in early 2020 until now several regions in Indonesia have begun to be exposed to Covid-19 and have caused changes in the order of human life which requires carrying out various activities at home according to government recommendations 
Jendral A. Yani Street Lorong Gotong Royong 9/10 Ulu Palembang South Sumatera

email jurnal: jurnalhon@univpgri-palembang.ac.ic situs web: http://www.univpgri-palembang.ac.id
Accredited

SINTA 3

to suppress the spread of the virus. During the pandemic, many activities are limited and it is possible that people will lose their movement (Kartiko, Juniarisca, Tuasikal, Prakoso, \& Nurhayati, 2020). Changes in behavior patterns are not only limited to social aspects but also occur in the world of education, including the learning process in higher education. (Yatulkhusna, Rini; Safaruddin; Usra, 2022) said personality development in the world of education is seen in the realization of individual potential and this can be used as a foundation or provision for individuals in the future. The demand to implement social distancing followed by a work from home policy requires lecturers to design a learning process that students can follow from their respective homes (Word). In line with (Yatulkhusna, Rini; Safaruddin; Usra, 2022) statement, to achieve educational goals, every individual must be able to innovate, especially in learning activities that must be followed by quality.

In response to the above, many lecturers have finally changed the learning model, which was originally a face-to-face learning process in class to online learning (online). Learning can be done synchronously or asynchronously through several platforms, for example: Zoom Meeting, Google Meet, Google Classroom, Edmodo, WhatsApp, etc. Along with the times and the rapid advancement of technology, the various platforms above can not only be accessed via computers/laptops, but even smartphones can be used so that it makes it easier for students to carry out the learning process.

Table tennis is a sport game that is played by two or more people and is played indoors using a small ball and a bat/racket as a bat. In the table tennis game, there are several basic techniques and they are included in the Table Tennis Learning course material which is one of the courses whose learning process uses the online system in the Department of Physical Education, Siliwangi University. The application of online learning requires the readiness of various parties, including universities, teachers (lecturers) and students. There are several obstacles in the online teaching and learning process, especially table tennis learning is a practical course that requires a clear demonstration so that the 
learning objectives can be achieved. Learning media is one solution that can solve these problems. Because the use of appropriate learning media will support the success of the learning process.

Quoted from katadata.co.id (2019), smartphone use in Indonesia is increasing from year to year, namely from 2016 - 2019 it has experienced a very rapid increase, from 65.2 million to 92 million users. This shows that in Indonesia smartphone users are very familiar. Currently, smartphone support is also growing rapidly with various functions, as stated (Kusniyati Harni, 2016). From the statement above, making learning media through smartphones is considered appropriate, besides that it can also reduce the negative impact on the use of smartphones which are usually only used for the needs of playing games. Therefore, in this study, researchers are interested in conducting a study with the theme "Development of Android Application-Based Table Tennis Learning Media". In this development research, the researcher wants to try to make an android-based application product named B-Pong which means Basic Pingpong, with the aim of this product being used as a medium to help the table tennis learning process which includes how to practice various basic techniques that must be mastered.

The formulation of the problem in the development of table tennis learning media based on this android application, namely: (1) How to develop an android-based table tennis learning media? (2) How is the feasibility of androidbased table tennis learning media to be used in the learning process?

Previous research conducted (Pratama, Herlambang, Kusumawardhana, \& Royana, 2020) entitled "Go Pong Learning Media of Android-Based Table Tennis Basic Techniques". The results of the research are: The development of learning media for basic table tennis techniques based on Android Go Pong at SMP Negeri 1 Juwana adopted 8 steps of development stages, learning media for basic table tennis techniques based on android Go Pong at SMP Negeri 1 Juwana has met the criteria for use in learning at SMP Negeri 1 Juwana. class, with details from the small scale which has an average of 68 increasing to 81 , in addition to the large 


\section{OLATRAGA}

JURIAL HUIIKCOLIRTGHA
Jendral A. Yani Street Lorong Gotong Royong 9/10 Ulu Palembang South Sumatera

email jurnal: jurnalhon@univpgri-palembang.ac.id situs web: http://www.univpgri-palembang.ac.id
Accredited

SINTA 3

scale test getting a value from 62 to 76 . Furthermore, from the n-gain test there is an increase in results, the same criteria are moderate but the results are different. From a small scale of 0.07 to 0.486 and a large scale from 0.263 to 0.374 . There is a rapid increase between book media and Go Pong media. The learning media for the basic technique of table tennis based on Android Go Pong is proven to be effective in improving student learning outcomes at SMP Negeri 1 Juwana. The problems in this study are; how is the development and how effective the GoPong media is for the basic technical material of table tennis. Meanwhile, the purpose of this study was to develop the Go-Pong media design for the basic table tennis technical material and test the effectiveness of the Go-Pong media on the basic table tennis technique material. The research method used is research and development (research and development). The data analysis technique used in the test is the normality test. It is calculated using the Lilliefors test formula, namely H0: Normal population distribution, if probability > 0.05, H0 is accepted., Ha: Population distribution is not normal, if probability $0.05, \mathrm{H} 0$ is rejected. The t-test was used for 88 Sports Window, Volume 05, No. 1, January 2020, p. 86-90 know the increase in student learning outcomes from the results of the pretest and posttest there is a significant difference or not. N-gain test, the criteria for improving learning outcomes interval coefficient criteria $\mathrm{N}$-gain $<0.3$ Low $0.3 \mathrm{~N}$ gain $<0.7$ Medium N-gain 0.7 High. There is also research that has been developed by another development carried out by (Prabowo, Andika; Raibowo, Septian; Eko Nopianto, Yahya; Sahri, 2021) which has produced a digital-based footwork test kit for the game of tennis. The purpose of his research is to make it easier for athletes and tennis coaches to improve their ability to train footwork as well as to facilitate the learning process of tennis footwork in lectures.

The application product made in the research above the material content only covers the scope of learning in junior high school (SMP), so that not all basic table tennis techniques are conveyed, because the application content is adapted to the curriculum of each school and according to learning needs. 
The research and development of table tennis learning media based on this android application, develops and produces table tennis learning media products based on android applications that can be used by teachers, lecturers, and even coaches in table tennis clubs. In other words, the android-based table tennis learning media application product that is made can be implemented in learning and sports achievement training. The content or basic techniques of the material presented are very complete, including basic table tennis techniques according to the name of the application, namely B-Pong (Basic Ping-Pong) which is useful for all circles. This application can be used as a guide for coaches in the process of coaching early childhood athletes. In addition, the advantages of this very efficient product can be easily installed on all smartphones without the need to use a quota when using it.

This study aims to produce a product, namely an android-based table tennis learning media. In particular, this research has the aim of providing table tennis learning innovations by applying android-based table tennis learning media. The general benefit in this research is to provide scientific insight related to table tennis learning media based on android applications. The benefits specifically for the world of education and the world of sports from this research are to provide alternative choices in using android application-based table tennis learning media for teachers, lecturers and coaches.

Learning is a process of communication between teachers, students, and learning media. Communication will not run (Cristianto, Johan, 2019). The teaching materials available in schools/campus are usually only in the form of textbooks, diktats and modules. Therefore, there is a need for a new breakthrough to make it more interactive, as stated by without the help of the means of conveying messages or media as it is said (Susanto, 2020). Learning Media is a tool that can help the teaching and learning process so that the meaning of the message conveyed becomes clearer and the goals of education or learning can be achieved effectively and efficiently (Nurrita Teni, 2018). (Muhson, 2010) says that learning media is a vehicle for distributing messages and learning 


\section{OLATRAGA}

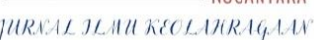

Jendral A. Yani Street Lorong Gotong Royong 9/10 Ulu Palembang South Sumatera

email jurnal: jurnalhon@univpgri-palembang.ac.ic situs web: http://www.univpgri-palembang.ac.id
Accredited

SINTA 3

information. He also said that well-designed learning media would greatly assist students in digesting and understanding the subject matter. Furthermore (Ramli \& Dangnga, 2002) said that learning media can be interpreted as anything that becomes a liaison between teachers and students in the delivery of subject matter. Meanwhile, Bertz in (Yuliana, Adelya Ika; Astra I Ketut BUdaya; Adi, 2018) explains the media as follows:

The main characteristics of the media into three main elements, namely, sound, visual, and motion. Visuals are divided into three, namely images, lines, and symbols which are a continuum of forms that are captured by the sense of sight. In addition, Bretz also distinguishes broadcast media (telecommunication) and recap (recording) media so that there are media classifications: (1) motion audio-visual media, (2) silent audio-visual media, (3) semi-motion audio-visual media, (4 ) motion visual media, (5) silent visual media, (6) semi-moving media, (7) audio media, and (8) print media.

Based on the understanding put forward by several experts, it can be concluded that learning media is a tool to convey a message or information related to learning, to achieve learning objectives that are more effective and efficient. Android is an operating system that is Open Source, which gives developers the freedom to develop an application (Efmi, 2018). According to Safaat, H (2012:1) in (Giyartono \& Kresnha, 2015) states "Android is an operating system for Linuxbased mobile devices that includes an operating system, middleware and applications. Android is a Linux-based operating system for mobile phones such as smartphones and tablet computers. Furthermore (Kusniyati Harni, 2016) explains that Android provides an open platform for developers to create their own applications for use by various mobile devices.

Smartphones (smartphones) and other touch-based mobile devices are very popular these days. Android was founded in Palo Alto, California, in October 2003 by Andy Rubin (founder of Danger), Rich Miner (founder of Wildfire Communications, Inc.), Nick Sears (former VP of T-Mobile), and Chris White (head of interface design and development). WebTV) to develop "smart mobile 
devices that are more aware of the location and preferences of their users". The initial goal of developing Android was to develop a sophisticated operating system intended for digital cameras. However, it was realized that the market for these devices was not large enough, and the development of Android was then shifted to the smartphone market to compete with Symbian and Windows Mobile (Welch, 2013).

The popularity of smartphones is largely due to their ability to run applications. Even though the iPhone and iPad are growing rapidly, Androidbased smartphone packages with their growing collection of Java-based applications are proving to be strong competitors. According to tech websites like The Register (www.theregister.co.uk/), not only do many iPhone/iPad developers make money selling their apps, many Android Developers also make money selling similar apps. (www.theregister.co.uk/2010/03/02/android_app_profit/).

The National Standard for Higher Education (SN-Dikti), as regulated in Permendikbud Number 3 of 2020 Article 1, states that the curriculum is a set of plans and arrangements regarding the objectives, content, and learning materials as well as the methods used as guidelines for the implementation of learning activities to achieve the goals of Higher Education. . The Higher Education Curriculum is an institutional mandate that must always be updated in accordance with the development needs and science and technology as outlined in the Learning Outcomes. The learning achievements of the physical education department in accordance with Permenristekdikti No 44 of 2015 include: (1) Attitudes, which are correct and cultured behavior as a result of internalizing and actualizing norm values which are reflected in spiritual and social life through the learning process, student work experience, research and/or or community service related to learning, (2) General skills, including general workability that must be possessed by every graduate in order to ensure the equality of graduates' abilities according to the level of the program and type of higher education, (3) Special skills, special work abilities that must be possessed by each graduate in accordance with the scientific field majoring in physical education, (4) 
Jendral A. Yani Street Lorong Gotong Royong 9/10 Ulu Palembang South Sumatera

email jurnal: jurnalhon@univpgri-palembang.ac.id situs web: http://www.univpgri-palembang.ac.id
Accredited

SINTA 3

Knowledge, mastering theoretical concepts in certain fields of knowledge in general and theoretical concepts in special sections in the field of Physical Education in depth, and able to formulate for problem solving. The rest of the learning outcomes are described in courses in which there are CPL (graduate learning outcomes) courses that deliver physical education graduates who have hard skills and soft skills and the achievement of educational goals.

One of the main courses of the Department of Physical Education is the Table Tennis Learning course. This course weighs 2 credits and is contracted in the fourth semester. The learning achievements of the Table Tennis Learning course are as follows, "Being able to formulate knowledge related to table tennis learning, and being able to practice various basic table tennis game techniques. The material in table tennis learning lectures are: Being able to explain and practice the basic techniques of push forehand backhand, drive forehand backhand, chop forehand backhand, Smash Forehand Backhand, Block Forehand Backhand, Service Forehand Backhand. The methods used in table tennis lectures are: Demonstration, command, practice, reciprocity, assignment and added various models and approaches that are tailored to the needs of the material.

In the 2019-2020 academic year, the odd semester, in March 2020, there was a change in the lecture process, because at that time the beginning of the pandemic in Indonesia had not yet ended. As a result of this incident, all lecturers changed the pattern of lectures from offline lectures to online lectures so that the content of courses in the odd semester of the 2020-2021 academic year was adjusted to current needs and conditions. Learning outcomes are more emphasized in the cognitive and affective domains, for assignments and student psychomotor assessments are given and adjusted to students' abilities. There are several platforms that are used to support the online learning process, namely, (1) Zoom cloud meeting, to deliver theoretical lecture studies, reflect and evaluate motion assignments given to students, (2) Classroom, to transfer and upload lecture materials such as lecture contracts, teaching materials, assignments, Mid-semester and Final Semester Examination questions, (3) Youtube, as an online video 
platform to integrate lecture content which is carried out via zoom as well as a student reference so that they can review what has been conveyed during lectures, (4) Googleform , as a platform for delivering and managing formative tests and questions for the Mid-Semester and Final Semester Examinations. Another application as a support for packaging content and information related to lectures to make it as attractive as possible is Canva.

\section{METHOD}

The method used in this research is the Research and Development (R\&D) method. According to (Sujadi, 2003) Research and Development is a process or steps to develop a new product, or improve an existing product, which can be accounted for. These products are not always in the form of objects or hardware (hardware), but can also be software (software), such as computer programs for data processing, android applications, classroom learning, libraries or laboratories, or models of education, learning, training, guidance, evaluation, management, etc. Meanwhile, according to (Sugiyono, 2011) research and development methods are: "research methods used to produce certain products, and test the effectiveness of these products."

Furthermore, Sugiyono (Sugiyono, 2011) explains that there are 7 (seven) steps or stages in research and development as shown in Figure 3.1, namely: (1) Potential and Problems; (2) Data Collection; (3) Product Design; (4) Design Validation; (5) Design Revision; (6) Product Trial; (7) Mass Production. Furthermore, experimental methods are also used during design validation and product testing.

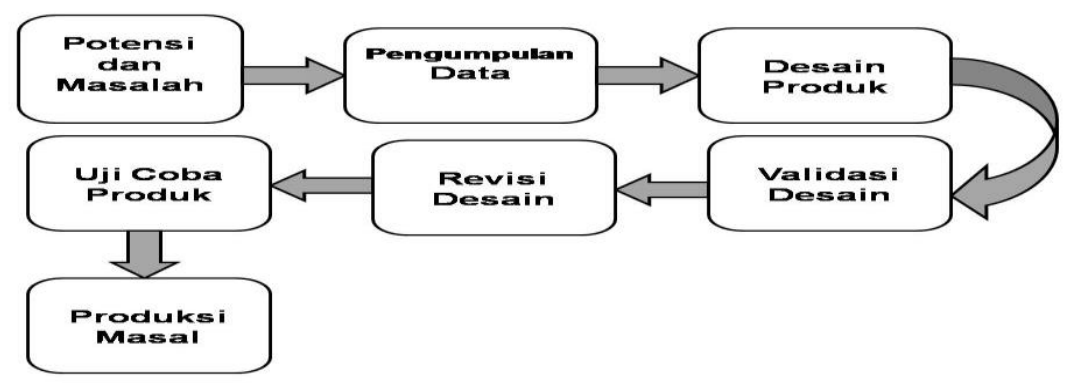

Figure 1. Research design and development of the Sugiyono model 
Jendral A. Yani Street Lorong Gotong Royong 9/10 Ulu Palembang South Sumatera

email jurnal: jurnalhon@univpgri-palembang.ac.id situs web: http://www.univpgri-palembang.ac.id
Accredited

SINTA 3

The application of the R\&D model will briefly be described below:

First, the researcher examines the potential and problems that exist when the implementation of online learning takes place and tries to innovate to solve these problems by reviewing various literatures.

Both researchers collect the data needed to design and develop the innovation model to be developed.

Third, the researcher designs the android application design, then determines the quality criteria for the validity, practicality and effectiveness of the android application and explains the techniques used to measure the quality of the android application.

The instrument used in this research is a questionnaire/questionnaire given to the Experts or Experts to determine or assess the feasibility of the android application that has been compiled. The Questionnaire material is arranged according to the expertise of the validators.

The feasibility test of the table tennis learning media based on the android application is carried out by competent validators or experts in their fields, namely media expert validators, material experts in the field of table tennis, and information technology experts. In addition, feedback is in the form of responses from students through a questionnaire/questionnaire given.

Data collection techniques in this study were using observation by distributing questionnaires, interviews and discussions and digging up information in the field through small and large-scale product trials. After the data has been collected, an analysis of the data resulting from these observations is carried out by paying attention to input from experts regarding the product being developed. Some of the suggestions given by the experts are used as the basis for product development, both from the aspect of learning media, the content of the basic table tennis technical material, as well as in terms of the appearance of the application by informatics experts. Through this process, products are made according to expert input. The responses from students as subjects were also considered who were involved when conducting product trials in the table tennis 


\section{DLAHRAGA}

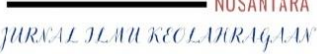

Jendral A. Yani Street Lorong Gotong Royong 9/10 U1 Palembang South Sumatera

Accredited

email jurnal: jurnalhon@univpgri-palembang.ac.id situs web: http://www.univpgri-palembang.ac.id

learning process. The results of these responses are taken into consideration to improve application products before the final step is mass production.

\section{RESULT AND DISCUSSION}

The product produced in this research is a table tennis learning media based on an android application called "B-Pong" which stands for Basic PingPong where the term ping-pong is another name for the game of table tennis. The purpose of developing this learning media is to provide convenience for lecturers, teachers and students in delivering and studying the basic materials and techniques for learning table tennis.

This application contains 5 basic stroke techniques in the game of table tennis in which there is an understanding of basic techniques, descriptions of motion, how to perform basic techniques. In addition to text that users can understand, there is also a complete video of all the basic techniques presented in this application, including: (1) basic forehand-backhand push techniques, (2) forehand-backhand drive basic techniques, (3) basic forehand chop techniques. backhand, (4) basic technique of Smash forehand-backhand, and (5) basic technique of Serve forehand-backhand. In addition, there are also examples of common errors that are often encountered in these basic techniques.

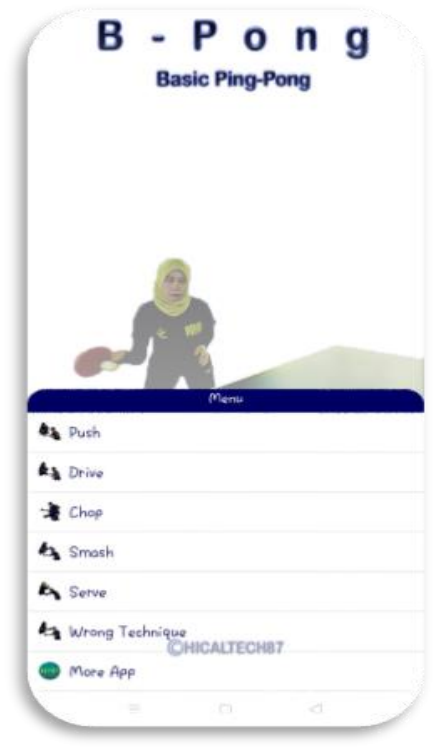

Figure 2. Main Page :B-Pong"

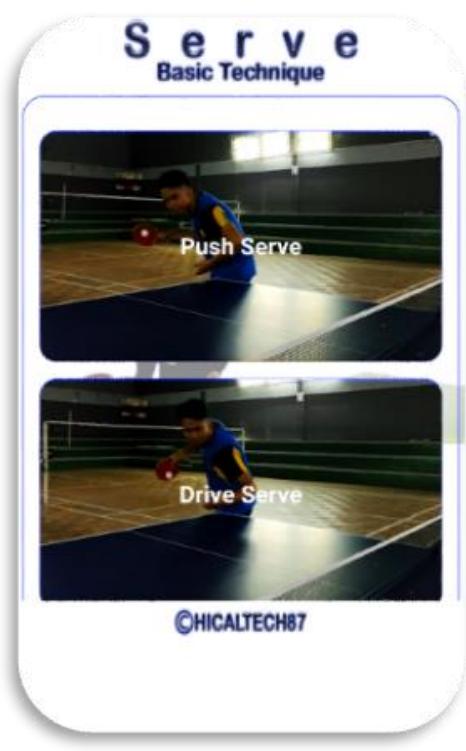

Figure 3. Pages of each category menu 


\section{OLATRAGA}

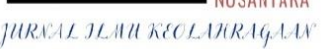

Jendral A. Yani Street Lorong Gotong Royong 9/10 U1u Palembang South Sumatera

email jurnal: jurnalhon@univpgri-palembang.ac.ic situs web: http://www.univpgri-palembang.ac.id
Accredited

SINTA 3

This android application-based table tennis learning media was designed and conceptualized by researchers and other research members which was translated into a programming language assisted by a second party, namely "hicaltech87". The software used in making gymnastics learning media based on this android application is Basic 4 Android version 11.0 which is abbreviated as B4a V11. The programming language used is Visual Basic which is then imported into Java by the software. This software uses 2 parts of coding, namely a module that functions as a manager of the command process to operate the display, and a designer that functions to create a menu page display, etc. The following is a picture of the B4A application:

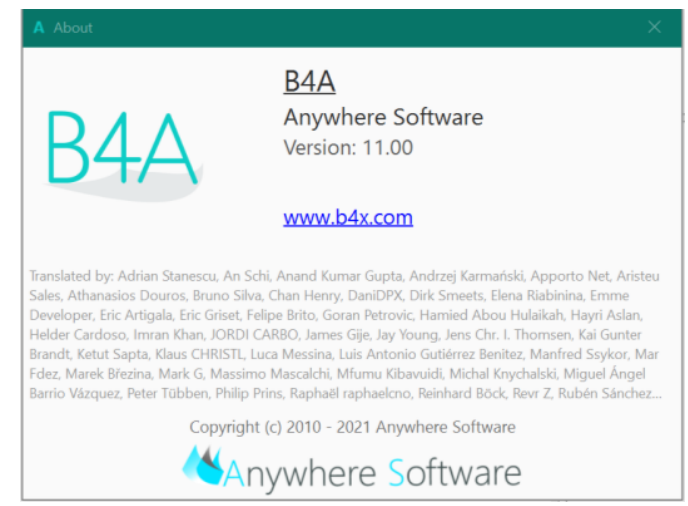

Figure 4. Software B4a V11

The development of table tennis learning media based on this android application uses the Sugiyono design model which contains 7 (seven) steps or stages in research and development, namely: (1) Potential and Problems; (2) Data Collection; (3) Product Design; (4) Design Validation; (5) Design Revision; (6) Product Trial; (7) Mass Production. Furthermore, experimental methods are also used during design validation and product testing.

The results of the product design validation process from experts (media experts, technology experts and material experts) who become validators through the questionnaires provided, it is concluded that the validators gave positive responses and approved the applications that the research team had developed and could be 
directly tested even though there were some inputs. to add other features that support the table tennis learning process.

The results of the product trial, received a positive response from application users, namely Siliwangi University Physical Education students. The majority of the responses obtained were that table tennis learning became easier to understand with this B-Pong application. In addition, students can also learn motion with near motoric concepts (imagine the perception of a motion that is seen visually) before entering a meeting in lectures.

In terms of appearance or commonly called the User Interface, the users provide very interesting responses so that it can increase interest in using the application, which means that the quality of the application interface that has been made is very good. Interface quality is the way the interface of an application attracts user interest in using the application (Park \& Kim, 2003).

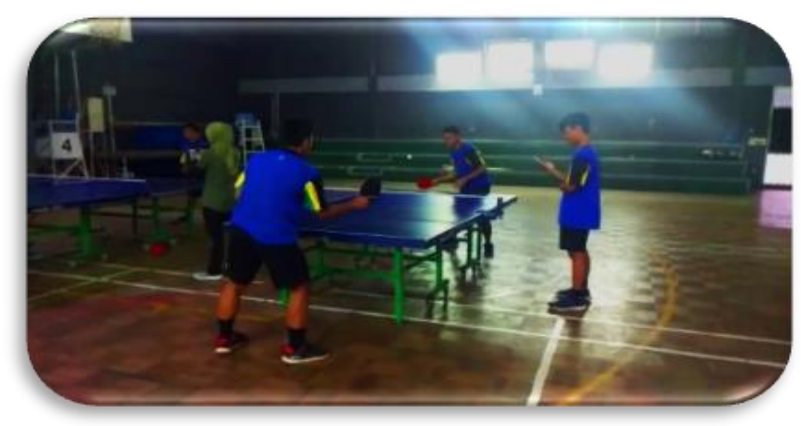

Figure 5. Testing Process for "B-Pong" Products

\section{CONCLUSION}

The results of this research and discussion are the production of a table tennis learning media product based on an android application called "B-Pong" which stands for Basic Ping Pong. Ping Pong is another name for table tennis that is already popular among the public. This application can be downloaded on google playstore with the application name "B-Pong" or can be downloaded at the following link, https://play.google.com/store/apps/details?id=hicaltech87.bpong.pingpongtableten nis 
Jendral A. Yani Street Lorong Gotong Royong 9/10 Ulu Palembang South Sumatera

email jurnal: jurnalhon@univpgri-palembang.ac.ic situs web: http://www.univpgri-palembang.ac.id
Accredited

SINTA 3

The results of the validation from the three experts (material experts, media experts, and information technology experts) were categorized as good and declared eligible to be used in the table tennis learning process. While the results of the feasibility test for the usability of this product are feasible and can be used in learning table tennis both offline and online. Some suggestions for further research or for other researchers, this product needs to be further developed both in terms of video or image quality and lighting, place background, and sound or audio. In addition, other researchers hope to be able to develop similar applications that discuss methods in training or teaching gymnastics. Showing systematics or steps how to teach or train easy movements to complex movements. Because in the field there are still very few reference sources, either in the form of applications or in the form of books.

\section{REFERENCES}

Cristianto, johan, w. D. D. (2019). Pengembangan media pembelajaran cricket berbasis mobile learning pada tim olahraga cricket universitas negeri malang. Gelanggang pendidikan jasmani indonesia, 3(2), 168-174.

Efmi, m. (2018). Pemanfaatan android dalam perancangan aplikasi kumpulan doa. Jurnal sains dan informatika, 1, 54-67.

Giyartono, a., \& kresnha, e. (2015). Aplikasi android pengendali lampu rumah berbasis mikrokontroler atmega328. (november), 1-9.

Kartiko, d. C., juniarisca, d. L., tuasikal, a. R. S., prakoso, b. B., \& nurhayati, f. (2020). Android - based sport board games for intellectual disabilities. 491(ijcah), 1144-1148.

Kusniyati harni, n. S. P. S. (2016). Aplikasi edukasi budaya toba samosir berbasis android. 9(1), 9-18.

Muhson, a. (2010). Pengembangan media pembelajaran berbasis teknologi informasi. Jurnal pendidikan akuntansi indonesia, viii(2). Retrieved from https://journal.uny.ac.id/index.php/jpakun/article/view/949

Nurrita teni. (2018). Pengembangan media pembelajaran untuk meningkatkan hasil belajar siswa. Misykat, 03, 171-187. Retrieved from https://media.neliti.com/media/publications/271164-pengembangan-mediapembelajaran-untuk-me-b2104bd7.pdf

Park, c., \& kim, y. (2003). Identifying key factors affecting consumer purchase behavior in an online shopping context. International journal of retail \& distribution management.

Prabowo, andika; raibowo, septian; eko nopianto, yahya; sahri, j. (2021). 
Development of digital based tennis footwork instruments. Halaman olahraga nusantara (hon), 4(ii), 282-293.

Pratama, i. D., herlambang, t., kusumawardhana, b., \& royana, i. F. (2020). Go pong: media pembelajaran teknik dasar tenis meja berbasis android. 05(1), 86-90.

Ramli, a., \& dangnga, t. (2002). Peran media dalam meningkatkan efektivitas belajar. $5-7$.

Sugiyono. (2011). Metode penelitian kuantitatif, kualitatif dan $r \& d$. Bandung: alfabeta.

Sujadi. (2003). Metode penelitian pendidikan. Jakarta: rineka cipta.

Susanto, r. (2020). Development of teaching material of sony vegas media based with anchored instruction models for tennis course in ikip budi utomo malang. 3(april), 623-627.

Yatulkhusna, rini; safaruddin; usra, m. (2022). Development of passing learning model on volyball. Halaman olahraga nusantara (hon) olahraga nusantara, 5(i), 32-44.

Yuliana, adelya ika; astra i ketut budaya; adi, i. P. P. (2018). Pengaruh penggunaan media audio visual terhadap hasil penggunaan media audio visual terhadap hasil belajar teknik dasar passing bola basket. 9. Retrieved from https://ejournal.undiksha.ac.id/index.php/jjp/article/view/14833/9099 